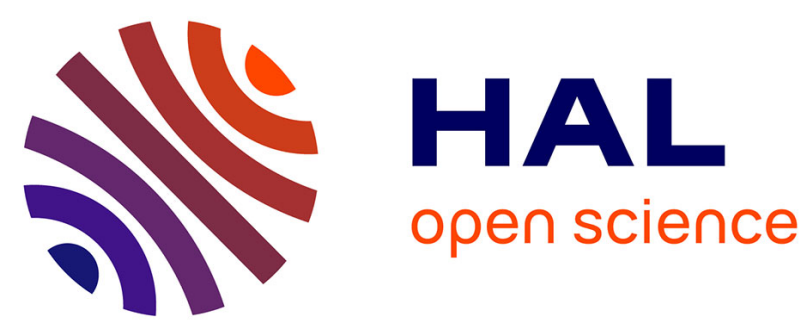

\title{
The influence of immature gonads on onset of gonadotropic hormone accumulation in the juvenile rainbow trout pituitary gland
}

\author{
L.W. Crim, Roland Billard, P.D. Genge, D.R. Idler
}

\section{To cite this version:}

L.W. Crim, Roland Billard, P.D. Genge, D.R. Idler. The influence of immature gonads on onset of gonadotropic hormone accumulation in the juvenile rainbow trout pituitary gland. General and Comparative Endocrinology, 1982, 48 (2), pp.161-166. 10.1016/0016-6480(82)90013-2 . hal-02728900

\section{HAL Id: hal-02728900 \\ https: / hal.inrae.fr/hal-02728900}

Submitted on 2 Jun 2020

HAL is a multi-disciplinary open access archive for the deposit and dissemination of scientific research documents, whether they are published or not. The documents may come from teaching and research institutions in France or abroad, or from public or private research centers.
L'archive ouverte pluridisciplinaire HAL, est destinée au dépôt et à la diffusion de documents scientifiques de niveau recherche, publiés ou non, émanant des établissements d'enseignement et de recherche français ou étrangers, des laboratoires publics ou privés.

\section{다(1)(2)}

Distributed under a Creative Commons Attribution - ShareAlikel 4.0 International 


\title{
The Influence of Immature Gonads on Onset of Gonadotropic Hormone Accumulation in the Juvenile Rainbow Trout Pituitary Gland
}

\author{
L. W. Crim, R. Billard, ${ }^{*}$ P. D. Genge, ANd D. R. IdleR \\ Marine Sciences Research Laboratory, Memorial University of Newfoundland, St. John's, Newfoundland, \\ AIC 5S7, Canada, and *Institute National de la Recherche Agronomique, Laboratoire de Physiologie des \\ Poissons, 7835 Jouy en Josas, France
}

Accepted October 18, 1981

\begin{abstract}
Juvenile rainbow trout received gonadotropic hormone $(\mathrm{GtH})$ treatment to investigate the response of the immature gonad and its effect on the onset of rising pituitary GtH levels, an early sign of initiation of sexual maturation in the teleost fishes. Brief exposure to GtH evoked increases in plasma androgens and significantly increased pituitary GtH in males; the accumulation of pituitary GtH was not observed in female trout which showed significant but smaller increases in plasma androgen resulting from $\mathrm{GtH}$ administration. There was no evidence of gonadal negative feedback in intact immature fish since pituitary GtH and plasma androgens remained at basal levels in castrate juvenile trout. Since the castrate male trout failed to respond to GtH injections, the data suggest that the immature gonad produces a steroid capable of triggering pituitary GtH production by hypothalmo-pituitary feedback in males.
\end{abstract}

The endocrine activity and interaction of the hypothalamus-pituitary-gonad axis (HPG) in sexually immature teleost fishes is poorly understood, and little is known about physiological events which trigger onset of sexual maturation in these animals. An early indication of the onset of sexual development in teleosts is a rising level of gonadotropic hormone $(\mathrm{GtH})$ appearing in the pituitary gland. Dramatic fluctuations in pituitary GtH accompany seasonal reproductive cycles in the precocious male Atlantic salmon parr (Crim and Evans, 1978; Dodd et al., 1978; Stuart-Kregor et al., 1981). These studies confirm much earlier work indicating that pituitary GtH activity may be directly correlated with reproductive development in teleosts.

Pituitary GtH in juvenile trout is extremely low but the GtH level is rapidly elevated following testosterone treatment (Crim and Evans, 1979). Recently, these observations were extended by demon- strating that one can manipulate the pituitary gonadotropin level in juvenile trout with either androgen or estrogenic steroid hormones (Crim et al., 1981). The physiological significance of steroid manipulation of pituitary GtH in juvenile trout would be partly elucidated if it could be demonstrated that the level of pituitary GtH in juvenile trout is influenced by androgenic steroid hormone activity of the immature gonads. Therefore, the present study was designed to give juvenile trout exogenous GtH treatment and to investigate the feedback influence of stimulated immature gonads on pituitary GtH activity.

\section{MATERIALS AND METHODS}

Experimental design. An initial experiment was conducted using $15 \pm 1 \mathrm{~g}$ sexually immature trout. Forty-one male trout were selected by abdominal inspection during the castration or sham castration surgical procedures. Castration was performed following anaesthesia with phenoxyethanol by making an incision in the ventral body wall. The anterior portion of 
the gonad near the liver was grasped with forceps and the entire length of the gonad was removed after pulling upward in an anterior direction. The wound was closed with nylon suture. No food was offered until the wound was healed. Fish were identified with a small fingerling tag installed immediately in front of the dorsal fin. One week following surgery the fish were treated with GtH (chum salmon) delivered in two perivisceral injections. A primary GtH dose $(0.1 \mu \mathrm{g} / 10$ $\mathrm{g}$ body wt) was administered, followed in 2 days by a final dose ( $1 \mu \mathrm{g} / 10 \mathrm{~g}$ body $\mathrm{wt})$. Fourteen days after the final injection the fish were sacrificed and pituitaries were collected for $\mathrm{GtH}$ analysis by radioimmunoassay.

A second study was performed on a group of intact immature rainbow trout of mixed sex $(16-35 \mathrm{~g})$. The fish were treated with $\mathrm{GtH}(2 \mu \mathrm{g} / 10 \mathrm{~g}$ body wt) twice a week for a period of 2 weeks (total of $4 \mathrm{GtH}$ injections). Samples of blood and pituitaries were collected at the time of autopsy carried out on Days 1 and 14 after the final hormone injection.

A third experiment was carried out to determine the influence of $\mathrm{GtH}$ treatment on intact and castrate juvenile trout. The trout weighed $11-48 \mathrm{~g}$. Nylon sutures were removed 2 weeks after surgery. GtH treatment, which began 3 weeks after surgery, again consisted of 4 perivisceral injections according to the schedule outlined in experiment 2. On Day 14 following the final $\mathrm{GtH}$ injection, blood and pituitaries were collected. At autopsy a gross microscopic inspection of the perivisceral cavity was conducted to determine the successful removal of gonads in castrate fish.

Hormone analysis. Pituitary and plasma $\mathrm{GtH}$ values were determined by radioimmunoassay methods previously described (Crim et al., 1975).

Androgens were also quantified by radioimmunoassay. The antibody to 11-ketotestosterone had a titer of $1: 30,000$ and was prepared and used as previously described (Idler and $\mathrm{Ng}, 1979$ ) except that 11 ketotestosterone and testosterone were isolated from plasma using paper chromatography (cyclohexane 100:toluene 70:methanol 100:water 25 for $6 \mathrm{hr}$ ). The antibody to testosterone was purchased from Radioassay Systems Laboratories (Carson, Calif.) and had good specificity for testosterone ( $\mathrm{Ng}$ and Idler, 1980). High specific activity $11-\left[{ }^{3} \mathrm{H}\right]$ ketotestosterone was prepared according to Truscott (1981) and purified along with $\left[{ }^{3} \mathrm{H}\right]$ testosterone at 3 -month intervals by paper chromatography.

Preparation of $\mathrm{Gt} H$ from chum salmon pituitaries. The Con AII $F_{2}$ GtH was prepared according to Idler et al, $1975 \mathrm{~b}$.

Statistical analysis. The Student's $t$ test was utilized to make appropriate group comparisons within each experiment.

\section{RESULTS}

An attempt was made in a preliminary experiment to determine the influence of brief GtH treatment on the pituitary $\mathrm{GtH}$ level in juvenile male rainbow trout. In intact and castrate control (saline-treated) males, pituitary GtH was extremely low or not detectable in the majority of individuals (data not shown). Likewise, pituitary GtH was undetectable in 10 of 11 castrate males receiving $\mathrm{GtH}$ treatment (1 pituitary value $0.5 \mathrm{ng}$ ). In contrast, 10 of 11 intact immature males treated with $\mathrm{GtH}$ had a measurable pituitary GtH level but the results were highly variable (range $0.5-47.9 \mathrm{ng} \mathrm{GtH}$ / pituitary). Therefore, in subsequent experiments, the dose of $\mathrm{GtH}$ and the number of injections were increased.

In the second experiment four injections of $\mathrm{GtH}$ were administered and pituitaries were collected on Days 1 and 14 following the final $\mathrm{GtH}$ injection. The data in Table 1 show that, compared with low female pituitary GtH levels, juvenile male pituitary GtH was significantly elevated on Days 1 and 14 of collection $(P<0.005 ; P<0.05$, respectively).

A third study was designed to confirm the effect of GtH injections on pituitary GtH in juvenile trout specifically in males. Castrate fish were included in this experiment as a control procedure for evaluating the capability of the immature trout gonad to respond to the GtH treatment. Blood samples were obtained in some fish on Day 1, following the final injection of $\mathrm{GtH}$, to allow determination of circulating $\mathrm{GtH}$ values achieved by exogenous hormone treatment. Plasma GtH values remained low in castrate and sham-castrate (intact) trout treated with saline (Table 2). However, cir-

TABLE 1

Pituitaky GtH Content in Juvenile Rainhow

TROUT AT 1 AND 14 DAYS FOLLOWING Treatment WITH GtH

\begin{tabular}{|c|c|c|}
\hline \multirow[b]{2}{*}{ Sex } & \multicolumn{2}{|c|}{ Pituitary GtH (ng) } \\
\hline & Day 1 & Day 14 \\
\hline Female & $6.26 \pm 1.51(5)^{a}$ & $2.43(5)$ \\
\hline Male & $158 \pm 35$ & $236 \pm 105$ \\
\hline
\end{tabular}

${ }^{a}$ Values are $\bar{X} \pm \operatorname{SE}(N)$ 
TABLE 2

Plasma Gth Concentration (Day 1) and Pituitary Gth Content (Day 14) following the Final InJection of GtH in Juvenile Rainbow Trout

\begin{tabular}{|c|c|c|c|}
\hline Sex & Treatment & $\begin{array}{c}\text { Plasma GtH } \\
(\mathrm{ng} / \mathrm{ml})\end{array}$ & $\begin{array}{c}\text { Pituitary GtH } \\
\text { (ng) }\end{array}$ \\
\hline \multicolumn{4}{|l|}{ Males } \\
\hline Sham castrate & Saline & $2.48 \pm 0.30$ & $1.02 \pm 0.58(6)^{a}$ \\
\hline Castrate & Saline & $4.06 \pm 0.42$ & $0.30 \pm 0.06$ \\
\hline Sham castrate & $\mathrm{GtH}$ & $277 \pm 41$ & $99 \pm 28$ \\
\hline Castrate & $\mathrm{GtH}$ & $152 \pm 45$ & $2.72 \pm 1.97(10)$ \\
\hline \multicolumn{4}{|l|}{ Females } \\
\hline Sham castrate & Saline & $2.86 \pm 0.30$ & $3.14 \pm 3.01(10)$ \\
\hline Castrate & Saline & $3.20 \pm 0.21$ & $0.28 \pm 0.03(10)$ \\
\hline Sham castrate & $\mathrm{GtH}$ & $367 \pm 33$ & $2.08 \pm 0.39(10)$ \\
\hline Castrate & $\mathrm{GtH}$ & $222 \pm 69$ & $0.31 \pm 0.05$ \\
\hline
\end{tabular}

${ }^{a}$ Values are $\bar{X} \pm \operatorname{SE}(N)$.

culating GtH was greatly elevated in the plasma of both male and female (castrate and sham-castrate) fish receiving the $\mathrm{GtH}$ injections. No increase in pituitary GtH was observed in response to just the castration of the sexually immature male and female rainbow trout (Table 2). In agreement with the results of the above experiment, GtH treatment of intact juvenile female trout failed to increase pituitary $\mathrm{GtH}$ levels. However, following GtH treatment of intact juvenile males, pituitary GtH significantly increased $(P<0.005)$ compared with castrate males receiving the $\mathrm{GtH}$ treatment. These data suggest that the testes of sexually immature trout have the capacity to stimulate increases in pituitary GtH by hormone feedback.

The search for a presumptive immature testicular steroid secretory product was begun with steroid radioimmunoassay analyses of plasma obtained from $\mathrm{GtH}$ treated juvenile trout. Initially, the plasmas obtained in experiment 2 were pooled according to sex. Steroid profile determinations (data not shown) indicated that testosterone and 11-ketotestosterone were the androgens present ( $11 \beta$-hydroxytestosterone not detectable); plasma estradiol- $17 \beta$ was found to be low and remained unchanged with time after withdrawal of $\mathrm{GtH}$ treatment. In experiment 3 individual de- terminations of androgen titers were conducted for plasmas collected on Days 1 and 14 after the final GtH injection (Table 3). In $\mathrm{GtH}$ treated (sham-castratc) males, in which accumulation of pituitary GtH had commenced, the levels of testosterone and 11-ketotestosterone were significantly increased $(P<0.005)$ compared with intact males recciving saline treatment. No significant increases in plasma androgens were observed in GtH treated castrate males. Plasma testosterone was detectable but low in intact (sham-castrate) female trout treated with GtH. In females 11-ketotestosterone was not detectable. Fourteen days after the withdrawal of GtH therapy, plasma androgen levels declined in males but the low testosterone level in females remained unchanged.

\section{DISCUSSION}

The life cycle of many teleosts can be divided into three periods of reproductive activity including juvenile, pubertal, and adult phases. Most of the work to date on endocrine control of fish reproduction deals with seasonal sexual development during the adult period (Billard and Breton, 1979) and therefore, little is known about endocrine interactions in the hypothalamopituitary-gonad axis (HPG) of sexually immature teleosts. 
TABLF 3

Plasma Androgen Concentrations (ng/ml) on Days 1 and 14 after the Final GtH INJECTION IN JUVENILE RAINBow Trout

\begin{tabular}{|c|c|c|c|c|c|c|}
\hline \multirow[b]{2}{*}{ Sex } & \multirow[b]{2}{*}{ Treatment } & \multirow[b]{2}{*}{$N$} & \multicolumn{2}{|c|}{ Testosterone } & \multicolumn{2}{|c|}{ 11-Ketotestosterone } \\
\hline & & & Day 1 & Day 14 & Day 1 & Day 14 \\
\hline \multicolumn{7}{|l|}{ Males } \\
\hline Sham Castrate & Saline & 5 & $5.4 \pm 1.7^{a}$ & - & $2.5 \pm 0.5$ & - \\
\hline Sham Castrate & GtH & 5 & $22.4 \pm 3.7$ & $3.5 \pm 0.9(11)$ & $9.5 \pm 1.2$ & $<0.5$ \\
\hline Castrate & GtH & 5 & $3.6 \pm 0.8$ & - & $1.8 \pm 0.4$ & - \\
\hline \multicolumn{7}{|l|}{ Females } \\
\hline Sham Castrate & $\mathrm{GtH}$ & 5 & $4.1 \pm 1.8(3)^{b}$ & $1.8 \pm 0.2(10)$ & $<0.5$ & $<0.5$ \\
\hline
\end{tabular}

Some observations suggest that the HPG of juvenile fish is poorly active, if at all. In Atlantic salmon parr plasma androgen levels are very low (Stuart-Kregor et al., 1981). Gonadotrophs are poorly developed in immature Atlantic salmon parr (Olivereau, 1976) and also in the pituitary of coho salmon fry (Leatherland and Lin, 1975). Plasma and pituitary GtH is extremely low in the juvenile trout (Crim and Evans, 1979, 1980) and immature Atlantic salmon parr (Crim and Evans, 1978; Stuart-Kregor et al., 1981). Furthermore, the present study showed that plasma and pituitary $\mathrm{GtH}$ remain unchanged following gonadectomy of both male and female juvenile trout. Hypersecretion of $\mathrm{GtH}$ in response to castration of adult rainbow trout has been reported (Billard et al., 1976, 1977); however, the failure of castration to influence GtH levels in juveniles suggests that steroid feedback is lacking and the HPG of juvenile trout may be inactive.

If the HPG in juveniles is quiescent as present information seems to suggest, it is of interest to determine what triggers the onset of sexual development in fish during the pubertal period. Crim and Peter (1978) showed that testosterone treatment induces a rapid rise of $\mathrm{GtH}$ in pituitaries of precocious male and immature female Atlantic salmon parr. Pituitary GtH activity is also stimulated by testosterone in the immature rainbow trout (Crim and Evans, 1979), and long-term treatment of sexually immature eels with estradiol triggers development of pituitary gonadotrophs (Olivereau and Chambolle, 1978, 1979; Olivereau and Olivereau, 1979a,b). Recent work by Crim et al. (1981) on steroid specificity of positive feedback agents suggests that only estrogen or aromatizable androgens are effective on $\mathrm{GtH}$ in the juvenile rainbow trout. Taken together, the above studies suggest that gonadal steroids may regulate the gonadotropic activity of the fish pituitary gland especially during the pubertal period of gonadal development, and also possibly gonadal recrudescence, when pituitary GtH levels are rapidly rising.

The immature gonads of juvenile rainbow trout are responsive to $\mathrm{GtH}$ as evidenced by stimulation of the formation of cyclic AMP by the gonad in vitro (Idler et al., 1975a), gonad histology (Upadhyay et al., 1978), stimulation of androgen production in vivo ( $\mathrm{Ng}$ and Idler, 1980 ), and enhancement of estrogen and vitellogenin synthesis (Idler and Campbell, 1980). The immature trout used in the present study responded to GtH stimulation by increasing the plasma androgen level. In male trout the steroid response to GtH treatment was sufficient to activate $\mathrm{GtH}$ accumulation in the juvenile pituitary gland. Since pituitary GtH activation in males was prevented by gonadec- 
tomy it appears that the immature testes is capable of evoking an increase in pituitary GtH via positive hormone feedback. Direct evidence of rising sex steroid levels during the early phases of gonad development in pubertal fish is very sparse although Stuart-Kregor et al., (1981) recently reported increased plasma testosterone levels in the precocious male Atlantic salmon parr in July. In juvenile female trout, pituitary GtH did not rise following GtH injections under the conditions of the present experiment. Perhaps the androgen production from the juvenile ovary was inadequate to produce a pituitary $\mathrm{GtH}$ response. It is also possible that plasma binding of androgens prevented pituitary GtH feedback in females since high bound to free androgen ratios have been reported to be sex specific in trout ( $\mathrm{Ng}$ and Idler, 1980). It is clear from previous studies (Crim and Evans, 1979; Crim et al., 1981), however, that immature female pituitaries are responsive to exogenous steroid hormone treatment since the rise in pituitary GtH in juvenile males and females is very similar.

When comparing the juvenile phase of teleosts and higher vertebrates, there appears to be major differences in the endocrine activity of the HPG. In mammals gonadotropins and gonadal hormones are readily detectable in endocrine organs and also in circulation (Grumbach et al., 1974). Increased gonadotropin secretion after castration indicates that negative feedback regulation of gonadotropin secretion is operational during all stages of sexual development beginning with the juvenile period. Changes in steroid hormone feedback sensitivity and target organ responsitivity are considered major factors in controlling onset of puberty in mammals. There have been a few reports of positive feedback effects of testosterone on gonadotropin secretion in mammals (Smith et al., 1977) and in birds (Wilson, 1978). In fish, further work is required to evaluate HPG activity in juveniles and in adults during the period of gonadal regression. The significance of positive steroid feedback during both of these phases of reproductive development is of great interest.

\section{ACKNOWLEDGMENTS}

The contribution of Mr. J. M. Walsh to the steroid radioimmunoassays is appreciated. This research was supported by NATO Grant 1305 and by the Natural Sciences and Engineering Research Council of Canada Grant A-9729 to L. W. C. Travel to Canada was supported by NRC Canada-CNRS France Exchange Scientist Grant to R.B.

\section{REFERENCES}

Billard, R., and Breton, B. (1979). Rhythms of reproduction in teleost fish. In "Rhythms of Activity in Fish" (J. E. Thorpe, ed.), pp. 31-53. Academic Press, New York.

Billard, R., Richard, M., and Breton, B. (1976). Stimulation de la sécrétion gonadotrope hypophysaire après castration chez la truite arc-enciel: variation de la résponse au cours du cycle reproducteur. C. R. Acad. Sci. Paris Ser. D 283, 171- 174 .

Billard, R., Richard, M., and Breton, B. (1977). Stimulation of gonadotropin secretion after castration in rainbow trout. Gen. Comp. Endocrinol. 33, 163-165.

Crim, L. W., and Evans, D. M. (1978). Seasonal levels of pituitary and plasma gonadotropin in male and female Atlantic salmon parr. Canad. J. Zool. 56, 1550-1555.

Crim, L. W., and Evans, D. M. (1979). Stimulation of pituitary gonadotropin by testosterone in juvenile rainbow trout (Salmo gairdneri). Gen. Comp. Endocrinol. 37, 192-196.

Crim, L. W., and Evans, D. M. (1980). LH-RH stimulated gonadotropin release from the rainbow trout pituitary gland: An in vitro assay for detection of teleost gonadotropin releasing factor(s). Gen. Comp. Endocrinol. 40, 283-290.

Crim, L. W., and Peter, R. E. (1978). The influence of testosterone implantation in the brain and pituitary on pituitary gonadotropin levels in Atlantic salmon parr. Ann. Biol. Anim. Biochem. Biophys. 18, 689-694.

Crim, L. W., Watts, E. G., and Evans, D. M. (1975). The plasma gonadotropin profile during sexual maturation in a variety of salmonid fishes. Gen. Comp. Endocrinol. 27, 62-70.

Crim, L. W., Peter, R. E., and Billard, R. (1981). Onset of gonadotropic hormone accumulation in the immature trout pituitary gland in response to 
estrogen or aromatizable androgen steroid hormones. Gen. Comp. Endocrinol. 44, 374-381.

Dodd, J. M., Stuart-Kregor, P. A. C., Sumpter, J. P., Crim, L. W., and Peter, R. E. (1978). Premature sexual maturation in the Atlantic salmon (Salmo salar L.). In "Comparative Endocrinology" (P. J. Gaillard and H. H. Boer, eds.), pp. 101-104. Elsevier/North-Holland Biomedical Press, Amsterdam.

Grumbuch, M. M., Grave, G. D., and Mayer, F. E. (1974). "The Control of the Onset of Puberty." Wiley, New York.

Idler, D. R., and Campbell, C. M. (1980). Gonadotropin stimulation of estrogen and yolk precursor synthesis in juvenile rainbow trout. Gen. Comp. Endocrinol. 41, 384-391.

Idler, D. R., and Ng, T. B. (1979). Studies on two types of gonadotropin from both salmon and carp pituitaries. Gen. Comp. Endocrinol. 38, 421-440.

Idler, D. R. Hwang, S. J., and Bazar, L. S. (1975a). Fish gonadotropin(s). I. Bioassay of salmon gonadotropin(s) in vitro with immature trout gonads. Endocrinol. Res. Commun. 2, 199-213.

Idler, D. R., Bazar, L. S., and Hwang, S. J. (1975b). Fish gonadotropin(s). II. Isolation of gonadotropin(s) from chum salmon pituitary glands using affinity chromatography. Endocrinol. Res. Commun. 2, 215-235.

Leatherland, J. F., and Lin, L. (1975). Activity of the pituitary gland in embryo and larval stages of coho salmon, Oncorhynchus kisutch. Canad. J. Zool. 53, 297-310.

$\mathrm{Ng}$, T. B., and Idler, D. R. (1980). Gonadotropic regulation of androgen production in flounder and salmonids. Gen. Comp. Endocrinol. 42, 25-38.

Olivereau, M. (1976). Les cellules gonadotropes hypophysaires du salmon de l'Atlantique: Unicité ou dualité? Gen. Comp. Endocrinol. 28, 82-95.

Olivereau, M., and Chambolle, P. (1978). Ul- trastructure des cellules gonadotropes de l'Anguille normale et après injection de'oestradiol. C. $R$. Acad. Sci. Paris 287, 1409-1412.

Olivereau, M., and Chambolle, P. (1979). Ultrastructure of gonadotrophs in the eel following oestradiol treatment. Proc. Indian Sci. Acad. B45, 478-82.

Olivereau, M., and Olivereau, J. (1979a). Effect of estradiol-17 $\beta$ on the cytology of the liver, gonads and pituitary, and on plasma electrolytes in the female freshwater eel. Cell Tissue Res. 199, 431-454.

Olivereau, M., and Olivereau, J. (1979b). Estradiolpositive feedback on gonadotropic $(\mathrm{GtH})$ cells in freshwater male silver eels. Gen. Comp. Endocrinol. 39, 247-261.

Smith, E. R., Samassa, D. A., and Davidson, J. M. (1977). Feedback regulation of male puberty: Testosterone-Luteinizing hormone relationships in the developing rat. Endocrinology 101, $173-180$.

Stuart-Kregor, P. A. C., Sumpter, J. P., and Dodd, J. M. (1981). The involvement of gonadotropin and sex steroids in the control of reproduction in the parr and adults of Atlantic salmon, Salmo salar L. J. Fish. Biol. 18, 59-72.

Truscott, B. (1981). An alternative method for the synthesis of $11-\left[{ }^{3} \mathrm{H}\right]$ ketotestosterone and $11 \beta$ $\left[{ }^{3} \mathrm{H}\right]$ hydroxytestosterone from $\left[{ }^{3} \mathrm{H}\right]$ cortisol. Gen. Comp. Endocrinol. 45, 409-411.

Upadhyay, S. N., Breton, B., and Billard, R. (1978). Ultrastructural studies on experimentally induced vitellogenesis in juvenile rainbow trout (Salmo gairdneri R.). Ann. Biol. Anim. Biochem. Biophys. 18, 1019-1025.

Wilson, S. C. (1978). LH secretion in the cockerel and the effects of castration and testosterone injections. Gen. Comp. Endocrinol. 35, 481-490. 